\title{
La fundación de Estados Unidos y el ocaso del pensamiento político clásico
}

\author{
The Founding of the United States \\ and the Decline of Classical Political Thought
}

\author{
David Corcho Hernández* \\ (D) https://orcid.org/0000-0002-5622-2281 \\ El Colegio de México, México \\ dcorcho@colmex.mx
}

Resumen: Este artículo analiza cómo la expansión del comercio y la manufactura afectaron al pensamiento político clásico en la última etapa de las Trece Colonias y los primeros años de Estados Unidos. Gracias a una combinación de análisis histórico y de teoría política, observa los cambios inducidos por la sociedad comercial en aspectos clave del pensamiento político clásico, como la representación, propiedad, libertad y el sentido de la historia. Su principal aporte está en buscar causas para esas transformaciones doctrinales en factores extradiscursivos, pues buena parte de la bibliografía sobre la historia de las ideas políticas en esta etapa se centra en los "lenguajes" e "ideologías".

Palabras clave: historia de los lenguajes políticos; republicanismo; pensamiento político clásico; Trece Colonias; revolución americana.

* Máster en Ciencia Política por El Colegio de México. Líneas de investigación: teoría política, historia de los lenguajes políticos, democracia representativa, liberalismo.

cómo citar: Corcho Hernández, D. (2021). La fundación de Estados Unidos y el ocaso del pensamiento político clásico. Secuencia (111), e1859. Dor: https://doi.org/10.18234/secuencia.v0i111.1859

(C) Esta obra está protegida bajo una Licencia Creative Commons Atribución-NoComercial 4.0 Internacional. 
Abstract: This article analyzes the way the expansion of trade and manufacturing affected classical political thinking during the last stage of the Thirteen Colonies and the early years of the United States of America. Using a combination of historical analysis and political theory, the author observes the changes caused by commercial society in key aspects of classical political thought, such as representation, property, freedom, and the meaning of history. Its main contribution is to find the causes of these doctrinal transformations in extra-discursive factors since much of the bibliography on the history of political ideas at this stage focuses on "languages" and "ideologies".

Keywords: history of political languages; republicanism; classical political thought; Thirteen Colonies; american revolution.

Recibido: 25 de mayo de 2020 Aceptado: 6 de octubre de 2020

Publicado: 2 de septiembre de 2021

\section{INTRODUCCIÓN}

T a revolución de las Trece Colonias provocó el nacimiento de la Unión y Lun nuevo tipo de régimen político: la primera república moderna en Occidente. Ese acontecimiento es famoso tanto por sus consecuencias prácticas como ideológicas. En este artículo me interesan las últimas en el ámbito de la política; aunque las primeras merecen toda nuestra atención y fueron el objeto de estudio de la investigación que justifica este texto (Corcho, 2019). Mi objetivo es mostrar cómo ese ideario evolucionó en las Trece Colonias y los primeros años tras la independencia al tomar contacto con las nuevas realidades sociales, económicas e institucionales.

Vale comenzar por explicar a qué me refiero con el término "pensamiento político clásico". Para este artículo es innecesario mencionar todas las características. Con explicar tres habré citado acaso las más importantes: el orden político ideal, la concepción de la historia y la relación entre libertad y propiedad.

El pensamiento político clásico extrajo su idea del orden político, en lo fundamental, de Aristóteles. Del estagirita proviene la suposición de que hay tres formas de gobierno: monarquía, aristocracia y democracia, y que el 
régimen ideal posee lo mejor de cada sistema. Estos autores, que van desde Maquiavelo hasta el siglo XVIII, aproximadamente (Pocock, 2002a), soñaban con un gobierno equilibrado en el que el monarca, los nobles y "el pueblo" -artesanos, comerciantes, campesinos, si acaso los primeros obreros- cooperaran para mantener la res publica. Cada uno de esos grupos tenía sus virtudes - por ejemplo, al monarca competía mandar con sabiduría-, y todos debían respetar una "supervirtud": el derecho a la existencia del prójimo. En esta supervirtud residía el bien común. Hasta la llegada de la modernidad, uno podía asegurar que los tres grupos cooperaban entre sí, tal vez no porque en realidad se respetaran, pero sí porque la vecindad forzaba a convivir. Y a causa de la "lentitud" de la historia. Lo cierto es que el orden social de un país europeo del siglo XVI se parecía más a su antecesor remoto del siglo x que a los estados modernos. En las sociedades premodernas las clases se mantenían más o menos en su lugar: el monarca y su corte en la cúspide, los aristócratas en el medio y el "pueblo" en la sima (Pocock, 1985).

Maquiavelo fue de los primeros en percibir que la politeia aristotélica exigía una sociedad casi inmóvil, donde cada grupo permaneciera en su lugar por largos periodos de tiempo. Una alteración en ese orden de cosas y el edificio político se derrumbaría. Pero hacia 1700 era evidente que el mundo cambiaba cada año lo suficiente como para decir que el tiempo había perdido su ritmo clásico. La república se tambaleaba sobre unos cimientos fatigados de cargar con la responsabilidad del bien común y que se sacudían sin cesar, queriendo sacarse de arriba el peso del aristotelismo.

Las Trece Colonias son un escenario ideal para el estudio del pensamiento político clásico y sus luchas con la modernidad. Lo son debido al tonillo antiguo de sus teóricos, cuyos razonamientos parecen sacados de un manual isabelino, de esos que debió leer John Locke para rebatir a Robert Filmer. Y aún más porque el arcaísmo de las ideas contrastaba con el vigor juvenil de la sociedad; muchos estudiosos de la época lo notaron (Appleby, 1984, 1992; Hartz, 1955; Huntington, 1990; Kalyvas y Katznelson, 2008). Cuando en Francia y Gran Bretaña los juristas hablaban sobre la creación de la ley por el hombre, de este lado del Atlántico seguían creyendo que el pueblo expresa la ley, pero no la crea. Pero también allí el pensamiento político clásico mutó en teorías más afines a la sociedad moderna. Y lo hizo rápido, en el espacio de una generación, como si quisiera recuperar el tiempo perdido en la carrera de la modernidad. Lo que sigue es un intento de explicación de ese cambio. 


\section{BOSQUEJO ECONÓMICO Y SOCIAL DE LAS TRECE COLONIAS}

A mediados del siglo xviII, la principal actividad económica en las Trece Colonias era la agricultura. A pesar de la importancia del comercio marítimo, la agricultura para el consumo doméstico sobrepasaba $800 \%$ el volumen de las exportaciones, cuyo monto oscilaba entre el 9 y $12 \%$ del PIB. Además, el $85 \%$ de la población trabajadora era rural (Perkins, 1980, pp. 35-36). La mayoría de los colonos eran propietarios de las tierras que trabajaban. Abundaban las tierras fértiles a bajos precios, por lo que resultaba fácil obtener una parcela. Las granjas se dispersaron a medida que la colonización se adentró en el Oeste, cuyas riquezas parecían infinitas y como si pudieran brindar eternamente el beneficio de la propiedad. La inmensidad del territorio y la inconstancia del contacto con otros seres humanos provocaron un sentimiento de soledad terrenal y una conciencia de la propia individualidad. De modo que allí donde sobrevivieron las pequeñas parcelas, el colono vivió hasta bien entrado el siglo XVIII alejado de sus pares por la anchura del espacio (Lemon, 1984, pp. 89-91).

Poco a poco los solitarios empezaron a acercarse entre ellos. Necesidades básicas de almacenamiento de víveres, recolección de impuestos, control de precios, mantenimiento de carreteras y el poderoso sentimiento religioso, juntaron a los colonos en los entronques de caminos, la cercanía de los ríos y los valles de clima bondadoso. Algunos pueblos comenzaron a incentivar la especialización técnica del trabajo desde finales del siglo xvir. En el sector artesanal, las autoridades lo hicieron a través de la disminución de los impuestos sobre los negocios emergentes, como herrerías, fábricas de ladrillos y molinos. Esta primitiva división del trabajo ahondó la separación entre el campo y la ciudad. Progresivamente, las granjas y las haciendas se convirtieron en unidades productoras para la exportación, a la vez que mantenían su capacidad fundamental como sustento del colono. Los centros urbanos, grandes y pequeños, se convirtieron en lugares de almacenamiento y embarque de las cosechas y materias primas destinadas a los mercados de Europa, Asia y América Latina. Para 1776, la fisonomía del país era predominantemente agrícola en el Oeste, pero hacia el noreste, en la costa atlántica, comenzaron a surgir ciudades dominadas por las clases mercantiles (Appleby, 1984, p. 47).

La única división importante antes y después de 1776 no ocurrió entre el campo y la ciudad, sino también entre el Norte -donde predominaban los pequeños propietarios, artesanos y comerciantes- y el Sur -el territorio de 
las plantaciones esclavistas-. Aunque la colonización siguió hasta finales del siglo XVII el curso esbozado en este acápite, a partir de entonces el Norte y el Sur comienzan a diferenciarse. En ambas regiones había distribuciones territoriales internas. El Norte puede dividirse en dos: Nueva Inglaterra y las Middle Colonies. En la región de Nueva Inglaterra -Massachusetts, Nueva Hampshire, Rhode Island y Connecticut- predominaba una economía rural autárquica y escasamente ligada al comercio, con valores puritanos muy fuertes. Las Middle Colonies -Nueva York, Nueva Jersey, Pensilvania y Delawareera el territorio del país en donde más profundamente había penetrado el capitalismo. El Sur presentaba también su propia división: el Chesapeake, el imperio del tabaco - Virginia y Maryland- y el Bajo Sur -las dos Carolinas y Georgia-, donde se cultivaban el índigo y el arroz. En el Sur abundaban los latifundios esclavistas y su sociedad rendía culto a los ricos hacendados, que hacían las veces de aristocracia sin títulos.

\section{AUTARQUÍA Y MERCADO EN EL NORTE}

Comencemos este acápite uniéndonos al doctor Alexander Hamilton en su viaje por Nueva Inglaterra y la Costa Central. Hamilton, físico escocés sin ninguna relación con el primer secretario del Tesoro de Estados Unidos, ha avanzado por la bahía del Chesapeake, las costas de Maine y las calles de Boston y Filadelfia junto a un sirviente negro. Lleva un diario -Itinerarium- en el cual escribe sus impresiones sobre la gente de los pueblos y las granjas que encuentra en el camino. Luego de soportar la perorata de los notables provincianos, que en vano intentaron catequizarlo para el protestantismo, y la compañía de unos holandeses borrachos y gritones durante la navegación por el río Hudson, el físico y el esclavo recalan en Nueva York. Allí se une a la expedición el reverendo John Milne, quien en breve comienza a padecer la misma aversión que sus acompañantes por las francachelas nocturnas de los holandeses. Hartos de la juerga, los viajeros desertan en la primera escala, cerca de una cabaña de troncos en donde viven un campesino y su familia. Hamilton y Milne poco saben sobre las costumbres del lugar, sólo que colinda con los bosques del Oeste. Los siete niños que los reciben en la ribera les parecen "salvajes y rústicos". En el diario nada se dice sobre cómo lucen o qué impresión causaron en los viajeros los otros miembros de la familia. Al parecer creyeron que la mejor forma de agasajar a los recién llegados era ofreciéndoles fresas silvestres, pues 
a poco de saludarlos, los convidaron a entrar a la cabaña con ese propósito. Entonces fue cuando los aventureros empezaron a examinar la vida material de la granja. Era el 23 de junio de 1744 (Hamilton, 1907, pp. 120-121).

Los dos hombres creyeron encontrar por aquellos rumbos una cultura primitiva, pero lo que vieron los sorprendió. Hamilton anotó en el diario que los "semibárbaros" mostraban notable inclinación por el lujo, pues al explorar la casa aparecieron "cosas caras y superfluas". Colgado de una pared, había un espejo con marco labrado en fina madera; en la cocina, media docena de cucharas y platos de estaño, una tetera y tazas de cerámica, vasos con ribetes de metal... Los objetos, comentó Milne, además de superfluos eran demasiado espléndidos para semejante casucha. A poco de enumerar las intromisiones del lujo, el reverendo expele un discurso aleccionador sobre las bondades de la vida frugal. Disgustados porque el campesino y la cabaña incumplen con sus arquetipos de austeridad, los dos hombres regalan unas monedas a la familia, dan unas palmadas condescendientes a los chiquillos en las espaldas y regresan al muelle a esperar otro velero, mientras rezongan sobre el relajamiento de las costumbres y el avance del vicio en compañía del silencioso sirviente negro.

¿Cómo habían llegado esos objetos a una granja cercana a la frontera? Los apuntes de Hamilton del día siguiente, 24 de junio, explican que pudo ser porque los campesinos iban de compras a un pueblo cercano o porque los comerciantes llegaban a esta zona remota. Sin importar la razón, el episodio muestra lo que parecía evidente para muchos colonos hacia mediados del siglo xviII: aunque lentamente, el mundo material que envolvía la vida cotidiana había comenzado a cambiar. El trasiego de mercancías había crecido lo suficiente como para poner a disposición de los campesinos, en las zonas más remotas del país, objetos que un siglo antes eran desconocidos para el hombre común y que seguían siendo motivo de fantasías para la mayor parte de la humanidad (Hamilton, 1907, pp. 121-122).

En Nueva Inglaterra la forma tradicional de pequeñas propiedades familiares se mantuvo estable por más tiempo, basada en el trabajo conjunto para garantizar el sustento doméstico, con contrataciones ocasionales de jornaleros y vecinos. Aquí el cambio de la sociedad tradicional a la economía mercantil ocurrió más lentamente que en las Middle Colonies y tampoco se vio la extensión del latifundio como en el Sur. Por lo que, hacia fines del siglo XVIII, la vida transcurría por el mismo cauce que 50 años atrás, con una estructura basada en la familia patriarcal, poca urbanización y una férrea moral puritana (Nash, 1984, p. 236). 
Las Middle Colonies comenzaron a adaptar sus economías al mercado imperial británico ya desde la primera década del siglo xviII, debido a la fertilidad de las tierras cercanas a la costa, muy adecuadas para el cultivo de granos. El campo se adaptó al comercio atlántico. Muchas granjas llegaron a destinar entre el 40 y $50 \%$ de sus cosechas a la exportación, sin necesidad de ver disminuido el nivel de vida de los agricultores (Nash, 1984, p. 236). En la costa proliferaban la pesca, la caza de ballenas y la industria naviera. Aparecieron nuevos pueblos y evolucionaron los que existían; comenzaba a notarse que los del interior eran centros de almacenamiento y distribución de granos conectados con los cercanos al mar, los cuales se dedicaban a nutrir el tráfico marítimo. Las autoridades coloniales, y más tarde los gobiernos independentistas, respondieron al auge del comercio con un plan de construcción de carreteras cuyos orígenes se remontan a la década de 1750. Pronto las Middle Colonies contaron con un moderno sistema de transporte terrestre; lo cual hizo más fácil la labor de los pueblos en la acumulación y resguardo de los productos agrícolas. Muchos habitantes urbanos debutaron en la manufactura -muebles, ron, carnes saladas, velas de aceite de cachalote, lingotes de hierro, harina de trigo-, con lo cual dio inicio una industria exportadora para Europa y América Latina (Daniels, 1989, pp. 429-450).

Gracias a la prosperidad del comercio atlántico, los grandes mercaderes comenzaron a invertir, hacia mediados del siglo xviII, en la manufactura $y$ otras industrias no directamente relacionadas con la agricultura. Por ejemplo, la familia Brown, de Rhode Island, edificó varios mataderos para proveer de carne salada a sus tripulaciones en altamar, así como a los plantadores del Caribe, quienes alimentaban con tasajo a sus esclavos. Al mismo tiempo, construyeron destilerías que convertían en ron las melazas de caña traídas de esa región. En la década de 1750, los Brown levantaron una fábrica de velas que utilizaba aceite de cachalotes. Para promover el consumo, adoptaron la estrategia de ponerle un logotipo a las cajas donde se transportaba la mercancía, que en la década siguiente, ya se embarcaba con destino a Europa y el Caribe. Hacia la misma fecha se aventuraron en el negocio del hierro. Construyeron una fragua en Providencia, región de Pensilvania donde abundaba la madera para alimentar el fuego. Las barras de hierro se comercializaban de tres formas distintas: eran directamente embarcadas con destino a Inglaterra, se vendían a otras firmas comerciales de Nueva York que las enviaban al mismo lugar, o iban hacia Massachusetts, en donde una forja con la que la familia tenía bue- 
nos tratos las convertía en clavos, que luego servían para construir barcos o también se vendían a Gran Bretaña (Perkins, 1980, pp. 92-93).

El negocio de los Brown es un ejemplo de cómo el capital comercial se iba transformando en algo distinto, para lo que el término "capital industrial" es exagerado y anacrónico, pero al menos sirve como medio de entender la lógica del proceso. Excepto los artesanos, casi toda la manufactura en las Trece Colonias era el resultado de la habilidad y el afán de lucro de los comerciantes involucrados en el tráfico ultramarino. En su mayor parte, la burguesía mercantil controlaba directamente la manufactura, la cual era vista como una actividad económica auxiliar -nunca independiente- del comercio (Perkins, 1980, pp. 92-93).

La extraordinaria fuerza política y social de la burguesía mercantil es una de las características distintivas de las colonias del Norte. En Massachusetts, por ejemplo, la clase mercantil dominó el Senado casi de modo ininterrumpido desde 1690, y para 1750 proveía la mitad de los representantes en la cámara baja (Perkins, 1980, pp. 95-96). Vale aclarar que en muchas colonias era necesario poseer tierras para poder votar u ocupar un cargo de gobierno. Estos requisitos eran comunes en el Sur, pero raros en el Norte. La revolución acabó con ellos en casi todos los estados, por lo que a inicios del siglo xIx la Unión tenía el más democrático de los sistemas electorales: entre el 40 y $60 \%$ de los hombres blancos podía votar (Keyssar, 2000, p. 20). Compárense esas cifras con el magro $2 \%$ de la población que tenía derechos electorales en Gran Bretaña por la misma fecha, unas 1200 familias adineradas y prestigiosas (Moore, 1976, p. 69). En cualquier caso, los comerciantes y, en menor medida, los artesanos, alcanzaron un alto estatus social ya desde el siglo XVII.

\section{ARISTOCRACIA Y MERCADO EN EL SUR}

Hacia 1776, las colonias del Sur poseían alrededor de la mitad de la población libre y el 90\% de los 480000 esclavos del país (Sheridan, 1984, p. 46). El sistema económico es muy similar en todas: la masa de esclavos africanos en la base y en la cima, los ricos plantadores, dueños de inmensas extensiones de tierra, mansiones y la vida de los esclavos. La concentración de riqueza era proporcional a la cantidad de esclavos, pues tierras y almas eran inversiones de capital. Y la concentración de tierras y esclavos otorgaba poder político y prestigio social (Perkins, 1980, p. 51). Ninguna clase acumuló tanto poder en 
las Trece Colonias como los hacendados sureños: eran latifundistas, señores de hombres, intelectuales, jefes de la milicia y hombres de Estado.

Se ha debatido en la academia estadunidense sobre si la economía de plantaciones era o no capitalista a fines del siglo XVIII y principios del XIX. ${ }^{1}$ El presente artículo algo tiene que ver con ese debate, pero la relación es indirecta. Siendo prudente, afirmaría que, fuera o no capitalista del todo -como lo sería tras la segunda mitad del siglo XIX-, ya se apreciaban rasgos capitalistas en ese sistema social. En lo que respecta al mundo de las mentalidades, mundo cuya historia está relacionada con la "histoire événementielle" por afinidad, nunca por determinaciones férreas, hay también ambivalencias, incluso antes de la época de estudio. Uno de los hacendados virginianos más prominentes de la primera mitad del siglo XVIII, William Byrd II, dejó un diario que revela cómo se comportaba esta clase hacendaria. La vida de Byrd está llena de paradojas. Era un hombre muy rico, con miles de acres de tierra y cientos de esclavos. Fue miembro del Senado y una voz influyente en los asuntos públicos de su Virginia natal. En su mansión, cerca del río James, acumuló una biblioteca espléndida e hizo traer tutores ingleses para la educación de sus hijos. Parece haber estado al corriente de los principales sucesos políticos y culturales de Europa. En sus relaciones con los esclavos, combinaba un cierto paternalismo -visitaba a los enfermos- y el afán por sacar el máximo provecho de ellos. En un artículo donde se discute la influencia del mercado en la vida de Byrd y otros hacendados, Michael Greenberg describe la mentalidad de la elite sureña como una mezcla de convicciones aristocráticas y burguesas. Byrd amasó su fortuna gracias a sus habilidades para lucrar, mientras intentaba crear un modo de vida aristocrático (Greenberg, 1977, pp. 429-456). Lo más llamativo del diario de Byrd y la investigación de Greenberg es la demostración de que la forma de pensar estaba cambiando ya en una época tan temprana como 1709, año al cual pertenecen la mayor parte de las entradas del diario.

En la región más cercana al Norte, el Chesapeake -Maryland y Virginia-, el cultivo fundamental era el tabaco. Este producto de lujo era cotizado en el mercado inglés, no porque los ingleses lo consumieran -apenas $15 \% \mathrm{del}$ tabaco que se importaba del Chesapeake se quedaba en Gran Bretaña-, sino

1 A manera de ejemplos, para una opinión favorable sobre la índole capitalista de la economía de plantaciones, véase Fogel y Engerman (1974). Una opinión contraria: Genovese y Fox-Genovese (1983). 
porque Europa continental lo compraba en grandes cantidades. Por tanto, el tabaco se convirtió en una de las principales fuentes de ingreso de Inglaterra en su comercio con Europa en el siglo XVIII (Perkins, 1980, p. 27). Las Actas de Navegación lo incluyeron entre los bienes que las colonias debían vender directamente a los comerciantes ingleses, quienes se encargaban de revenderlo a mayor precio en el mercado europeo (Perkins, 1980, p. 30).

La mano de obra esclava vino a sustituir a los arrendatarios blancos como base laboral de la economía tabacalera entre 1680 y 1720 . Para el primer cuarto del siglo xviII, la región del Chesapeake mostraba el tipo de propiedad latifundista y esclavista, especializada en la exportación, la cual encontraremos durante la era revolucionaria. Después de 1730, los comerciantes escoceses acapararon el comercio de tabaco a cambio de créditos a bajo interés que ofrecieron a los plantadores (Perkins, 1980, p. 28). Estos créditos fueron una de las herramientas más importantes en el crecimiento de toda la economía de plantaciones, no sólo del tabaco, porque permitieron una rápida acumulación de capital en tierras y esclavos. Luego de la independencia, la eliminación de los créditos redujo el cultivo del tabaco, lo que demuestra cuán dependiente del capital financiero inglés era la economía del Sur. Sin el mercado imperial los plantadores de tabaco no hubiesen acumulado tanta riqueza (Perkins, 1980, pp. 30-31).

El índigo y el arroz se convirtieron en los principales productos de exportación en el Bajo Sur -Carolina del $\operatorname{Sur}^{2}$ y Georgia- durante el siglo xVIII, ya que estas plantas semitropicales se adaptaban bien a las tierras bajas y húmedas de Carolina del Sur y Georgia. Como el tabaco, el arroz debía pasar antes por las manos de los mercaderes ingleses, quienes lo reexportaban a Europa, mientras que el índigo se utilizaba casi en su totalidad por la industria textil británica -el índigo es la planta que, a falta de colorantes artificiales en el siglo XVIII, producía el color azul añil. Para la década de 1770, las exportaciones de arroz ascendían a 312000 libras esterlinas anuales y las del índigo a 117 000- (Perkins, 1980, p. 29). El índigo creció rápidamente en el Bajo Sur desde que, en 1748, el Parlamento aprobó un subsidio de seis peniques por cada libra importada para favorecer a la industria textil británica. Es cuestionable si el índigo podía subsistir sin la contribución del gobierno inglés, ya que, tras la independencia y el fin de este subsidio, las plantaciones lan-

${ }^{2}$ Carolina del Norte pertenece a la misma región, pero allí el principal producto de exportación era la madera y había pocos latifundios esclavistas. 
guidecieron y prácticamente habían desaparecido en 1790. La catástrofe del índigo, aún más que el resentimiento del cultivo del tabaco, demuestra cuán dependiente del mercado imperial británico era la economía de los plantadores sureños. El arroz se salvó de una muerte fulminante debido al incremento del consumo doméstico -muy grande incluso en la época en que se exportaba a Gran Bretaña-y el de Europa Oriental y el Caribe (Perkins, 1980, p. 56).

El sistema que unía al plantador con el comerciante inglés evitó la aparición de una burguesía comercial en el Sur y concentró el poder económico en los hacendados. Los ríos caudalosos y las muchas entradas de la costa que aproximaban el mar al interior del país, favorecieron la navegación fluvial y facilitaron el contacto entre las haciendas y los barcos sin necesidad de intermediarios locales. Las cosechas se acumulaban en las haciendas de los plantadores o en sus vecindades y desde allí se embarcaban directamente en los navíos. Hacia 1740, los comerciantes escoceses establecieron factorías en el Chesapeake y el Bajo Sur para reducir los precios de adquisición y transporte de las cosechas. Junto a esta práctica agresiva, con el propósito de ganarles la partida a los competidores de Liverpool y Londres, los escoceses extendieron los créditos y redujeron las tasas de interés. El nuevo sistema ofrecía ventajas en comparación con el antiguo, pues el plantador se libraba de los riesgos e incertidumbres de una larga travesía a través del Atlántico y obtenía más dinero (Perkins, 1980, p. 56).

Es claro por qué no prosperó la burguesía comercial en el Sur al mismo nivel de sus pares norteños: no tenía muchas oportunidades entre los hacendados y los comerciantes ingleses, quienes monopolizaban la cadena de producción y comercialización del arroz, el índigo y el tabaco. Por la misma razón, las ciudades meridionales crecieron poco en el siglo xvIII. Norfolk y Baltimore, por ejemplo, apenas rebasaban los 6500 y 5000 habitantes, respectivamente, en 1775. Charleston, el puerto más importante del Bajo Sur, ni siquiera alcanzaba esta cifra. Por la misma época, Filadelfia tenía 45000 habitantes. Las tres ciudades del Sur comerciaban fundamentalmente con el Caribe, el único lugar donde los escasos mercaderes sureños podían lograr éxitos. Pero el comercio con las West Indies era pequeño en comparación con el del Atlántico: apenas 194000 libras esterlinas, en comparación con 1213000 a que ascendía en 1772 el tráfico de exportación sólo hacia la "madre patria", sin contar el resto de Europa (Perkins, 1980, p. 28).

El tabaco, el índigo y el arroz alimentaron el prestigio y la riqueza de los terratenientes sureños. Su modo de vida era extremadamente lujoso y no 
tenían reparos en demostrarlo. Por ejemplo, Charleston contenía la colección más grande de habitantes ricos en las Trece Colonias para 1776; la mayor parte eran plantadores absentistas que pasaban la mitad del año disfrutando de sus mansiones. Además, los hacendados poseían enorme poder político en las colonias del Sur; los gobiernos de la región se componían abrumadoramente de ricos plantadores. Debido al poderío del patriciado esclavista, el Sur se asemejaba más que el Norte a la estructura social de Inglaterra. Pero había diferencias entre ambas clases sociales. La gentry inglesa obtenía la mayor parte de su renta del alquiler de grandes parcelas a los arrendatarios. En los renteros grandes y medianos recaía la responsabilidad de hacer producir las tierras. A los terratenientes les importaba solamente que conservaran los predios en buen estado y que pagaran sus cuotas a tiempo. Gracias a la libertad de que gozaban, los arrendatarios se convirtieron en la fuerza de choque del capitalismo británico bajo el amparo político de la gentry. Este sistema permitió que la gentry mantuviera un modo de vida que se basaba en el ocio y el desprecio del comercio y el trabajo manual (Moore, 1976, p. 30). Por el contrario, pocos hacendados sureños se hicieron ricos dedicándose exclusivamente a la agricultura. El típico plantador sureño se aventuraba en cualquier empresa que pudiese reportarle alguna ganancia; era común que prestara dinero a sus vecinos menos ricos, que comprara sus cosechas para revenderlas a mayor precio en Europa o que hiciera de intermediario en la importación de bienes manufacturados (Perkins, 1980, pp. 58-60).

\section{EL PENSAMIENTO POLÍTICO CLÁSICO SE ENFRENTA A LA MODERNIDAD}

¿Cómo afectaron estos cambios económicos y sociales al pensamiento político predominante en las Trece Colonias antes de la revolución? El pensamiento político clásico establecía, siguiendo una tradición que los historiadores no se ponen de acuerdo si atribuir a Aristóteles o a Teofrasto, dos dominios separados en la reproducción material de la vida: oikonomika y chrematistika. La oikonomika era la gestión de una propiedad doméstica, el oikos. A la cabeza del oikos estaba el patriarca, dueño de animales, personas y cosas, las que se encontraban en la base de esa sociedad en miniatura, en donde los últimos garantizaban la existencia libre del primero. La chrematistika estaba más allá del oikos: el intercambio mercantil con el propósito de lucrar. Por supuesto, los 
dos grandes griegos fueron conscientes de que un patriarca astuto bien podía ingresar en el ámbito del lucro para aumentar el bienestar del oikos, pero en su pensamiento hay una tendencia a privilegiar el mundo autosuficiente de una propiedad muy parecida a una tribu pequeña. De esta familia antigua salía el ciudadano a discutir en el ágora y a hacer la guerra para defender lo que le daba sentido a su vida: la libertad. ¿Pero de qué libertad hablaban? No hay aquí una noción psicológica o naturalista de la libertad, aunque cualquiera de las dos podría ajustarse a lo que pensaban sobre ella. Saltando por encima de esas profundidades a las que se entregarán más tarde psiquiatras y filósofos, y sin querer buscar otras explicaciones para el individuo libre salvo las sociales, los griegos de la edad clásica pensaban que la libertad era algo muy concreto: si un hombre poseía tierras, armas y esclavos era libre (Pocock, 2002b, p. 351).

Las Trece Colonias rompen en dos puntos con la tradición clásica. Primero, porque ya a principios del siglo xviII la burguesía comercial gozaba de reconocimiento público en las colonias del Norte. Esto significaba que un grupo de hombres había asegurado su libertad, ya no por la posesión de tierras, sino por la tenencia de mercancías; es decir, bienes que pronto dejarían de ser suyos. La tierra era una propiedad estable, pero con el advenimiento del capitalismo ya no quedaba claro qué era propiedad y qué mercancía. ¿Qué se poseía en realidad si lo poseído pronto abandonaría nuestras manos? ¿Una cosa así merecía el nombre de propiedad o debía cambiarse por otro? En efecto, el mercado estaba transformando la noción misma de propiedad. Segundo, porque incluso los hacendados se implicaban en el comercio y algunas actividades manufactureras. En su estudio sobre los latifundistas sureños, Greenberg (1977) demuestra que el anhelo de los plantadores de parecerse a la gentry inglesa sirvió para fomentar el capitalismo y eliminar las impugnaciones morales al afán de lucro. No queda claro si los plantadores sureños eran conscientes de que su comportamiento poco tenía que ver con el desdén de la gentry por el comercio. Lo que resulta inobjetable es que asimilaron un ethos acorde con el capitalismo, aunque su meta fue imitar la conducta de una clase que despreciaba la moral burguesa.

En Gran Bretaña y sus colonias, hacia fines del siglo xvir y principios del XVIII la herencia política clásica comenzaba a escindirse en dos corrientes cuando se preocupaba por la relación entre propiedad y libertad: una aristocrática y otra democrática. Para la aristocrática, la libertad y la propiedad son privilegios; para la democrática, derechos naturales. Analicemos estas diferencias de criterio con mayor detenimiento. Primero, es necesario aclarar 
el factor común: ambas asumían que la propiedad era el sustento material de la libertad. Un pensador de índole aristocrática habría dicho que la diosa Fortuna repartía caprichosamente la propiedad y que el hombre nada podía hacer para cambiar esa suerte. Los afortunados eran libres y, por lo tanto, podían y debían -ambas cosas- ejercer el mando de la sociedad. El legislador tenía que adaptarse a esta realidad, a la desigualdad inherente al desarrollo social. Los demócratas coincidían en que Fortuna era caprichosa, pero pensaban que podía engañársela. Un legislador sabio trataría de hacer que todos los miembros de la sociedad gozaran de propiedad, convirtiendo a cada uno en dueño de su propio destino. Al contrario de lo que pesaban los aristocráticos, la realidad se adaptaría a los deseos del legislador. Como consecuencia, la desigualdad se ve como susceptible de alteraciones, como una exterioridad que el hombre podía dominar y someter (Pettit, 1999, p. 42).

Pero en el transcurso de la querella ideológica aparecieron contradicciones. ¿Quién tiene derecho a participar en la cosa pública? Los aristócratas dijeron que sólo un grupo pequeño de la sociedad. Así pues, la república era para ellos una comunidad política de privilegiados. Los demócratas contestaron que todos tenían derecho, porque todos eran.... ipropietarios, libres? La vertiente democrática del pensamiento político clásico tropezó rápidamente con un escollo teórico: no todos disfrutaban de riqueza e independencia personal. Los demócratas sabían que el mundo no tenía por qué ser un dechado de virtudes, pero suponían que la injusticia era tan poco natural como la justicia. ¿Cómo justificar la creación de esa justicia artificial si era una violación del orden natural? Gracias al recurso del derecho natural moderno. Colocaron junto al mundo injusto otro mundo de calidad superior, mundo intangible y metafísico, de donde provenían unos "derechos universales" que nadie podía violar. Y entre esos derechos universales estaban la propiedad y la libertad (Casassas, 2010, p. 33). Así pudieron asegurar que si el legislador intervenía para corregir las injusticias lo hacía en cumplimiento del mundo verdadero, el de los derechos universales, y continuaron creyéndose tan realistas como sus contrincantes. Pero, vale recordarlo, tanto para ambas corrientes la propiedad era la condición necesaria de la libertad y la república.

Cuando las relaciones mercantiles penetraron el "orden natural" del mundo premoderno -ni tan ordenado ni tan natural, pero más desprovisto de efervescencia que el crecimiento del intercambio mercantil-, los acontecimientos comenzaron a verse desde una perspectiva distinta. Si los cambios habían inclinado la balanza a favor de la crematística, ¿valía la pena seguir 
repitiendo que el hombre libre era quien poseía un oikos y que sin este perdería su libertad? A fines del siglo xviII el pensamiento colonial comenzaba a observar el comercio y la industria con mirada distinta a la de los humanistas de viejo cuño. Hamilton es acaso el mejor ejemplo de cuánto poder había alcanzado este ideario en América del Norte. En El Federalista número 12, expresó de manera elocuente:

La prosperidad del comercio está considerada y reconocida actualmente por todo estadista ilustrado como la fuente más productiva de la riqueza nacional y, por lo tanto, se ha convertido en objeto preferente de su atención política. Multiplicando los medios de satisfacer las necesidades, promoviendo la introducción y circulación de metales preciosos, objetos preferidos de la codicia y del esfuerzo humanos, se vivifican y fortalecen los cauces de la industria, haciéndolos fluir con mayor actividad y abundancia. El diligente comerciante, el laborioso agricultor, el activo artesano y el industrioso fabricante, los hombres de todas las clases, aguardan con vehemente expectación y creciente afán esta agradable recompensa a sus penalidades (Hamilton, Madison y Jay, 1990, p. 55).

Este pasaje es notable por sus muchos guiños y connotaciones. Analicémoslo con detenimiento. No es la tierra o el oikos el origen del progreso y la felicidad material, sino el intercambio mercantil. "La prosperidad del comercio está considerada [...] como la fuente más productiva de la riqueza nacional." Pero Hamilton no se detiene aquí; en la misma oración dice: "la prosperidad del comercio [...] se ha convertido en objeto preferente" de la "atención política" de los gobernantes ilustrados. Aparece en breve la relación que todo pensador clásico habría admirado, es decir, entre la política y la economía. Pero esa relación ya no es, como en Aristóteles, entre oikonomika y politeia, sino entre politeia y chrematistika. El legislador ha dejado de servir al oikos y se ha puesto a disposición del lucro. Y si hubiera que buscar hasta qué punto el cambio es radical, observemos la frase donde declara que la multiplicación de las necesidades y la circulación de metales preciosos son los "objetos preferidos de la codicia y del esfuerzo humanos". En efecto, la meta ha dejado de ser la salvación colectiva. Su lugar lo ocupan ahora la "codicia" y el bienestar material. Lo que vemos aquí es un elogio de la crematística en toda la regla.

Hamilton no era una rara avis en las Trece Colonias; no se lo puede considerar una especie de genio solitario que vislumbró el futuro de Estados Unidos, razón por la cual deberíamos desestimar sus ideas en vista de que 
no resumen el pensar de la sociedad estadunidense de finales del siglo XVIII. Por el contrario, la ideología favorable a la crematística tenía ya su espacio en el sistema de valores, como lo prueba Pauline Maier (2010) en su libro Ratification. The people debate the constitution. En esa obra, Maier relata cómo la autoridad del gobierno federal para recaudar impuestos y la posible eliminación de las tarifas arancelarias entre estados fue probablemente el asunto que más preocupó a los delegados durante los debates de ratificación que siguieron a la Convención de Filadelfia. Inquietaba a los asambleístas que las tarifas federales fueran demasiado altas, pues una de las grandes ventajas de la Unión sería la eliminación de esos obstáculos al comercio. Y al ver que los beneficios serían mayores que los inconvenientes, aquellos hombres pragmáticos no dudaron en dar su voto favorable (Maier, 2010, p. 157). No por gusto en El Federalista número 11, Hamilton lanzó el siguiente mensaje en medio del debate que decidiría el futuro de la Unión:

Un tráfico sin trabas entre los Estados intensificará el comercio de cada uno por el intercambio de sus respectivos productos, no sólo para proveer a las necesidades domésticas, sino para la exportación a mercados extranjeros. Las arterias del comercio se henchirán dondequiera y funcionarán con mayor actividad y energía por efecto de la libre circulación de los artículos de todas las zonas [...]. El comerciante aficionado a meditar percibirá en seguida la fuerza de estas observaciones y reconocerá que la suma de la balanza comercial de los Estados Unidos sería seguramente mucho más favorable que la de trece estados sin unión o unidos parcialmente (Hamilton, Madison y Jay, 1990, pp. 52-53).

Este llamado buscaba lectores receptivos, quienes inevitablemente debían ser hombres ligados al comercio y la producción con fines lucrativos. Sin la expansión del mercado y las ideologías que lo explicaban, el discurso de Hamilton habría quedado como una curiosidad retórica. Y lo que es más importante, el ansia por derribar barreras arancelarias entre estados muestra hasta qué punto este modo de vida y sus justificaciones estaban ya asentados en Estados Unidos. De los fragmentos de El Federalista y el libro de Maier, uno llega a la conclusión de que los colonos estaban inmersos en el mundo del comercio, se preocupaban por echar abajo los obstáculos a la crematística, eran pragmáticos y materialistas.

Como se observa, en la idea de que el comercio expande y perfecciona la naturaleza humana hay una noción implícita de orden natural. Pero tiene 
diferencias significativas con las formas expuestas aquí, la aristocrática y, especialmente, la democrática. El pensamiento aristocrático aceptaba el imperio del destino, que hacía a unos ricos y a otros pobres. Dos características a tener en cuenta: primero, en la corriente aristocrática las clases sociales solían ser posiciones fijas, incambiadas por la historia, en las que se acomodaba a la aristocracia en la cima y a los granjeros, artesanos y comerciantes en el abismo. Segundo, la fuerza que confería los dones y las carencias, el hado, era misteriosa; el hombre no podía conocer su mecanismo y, por tanto, no podía dominarla ni cambiarla. Los pensadores democráticos, tras observar que una teoría de esta índole era la mejor justificación para la desigualdad, intentaron cambiarla por otra. La solución fue desterrar el orden natural a una región fuera del tiempo y del cambio, paraíso de ideas puras donde ni los hombres, ni el azar, podrían corromper los sagrados derechos universales. A diferencia de la visión pesimista del bando aristocrático, ese orden natural era cognoscible. Pero los derechos naturales no cabía someterlos a la voluntad transformadora del hombre; el ser humano sólo podía manifestarlos, nunca alterarlos. "[Freedom] is a natural right which no creature can give, or hath a right to take away” (Downer, 2002, p. 141). Entonces, ¿por qué la visión de los ilustrados del siglo xviII, los hombres que observaban con alegría o con resignación, pero nunca con horror, la economía comercial y el cambio acelerado de la naturaleza y la sociedad, era distinta a la de los antiguos ideólogos? Porque el hombre comenzaba a verse como un animal histórico, cuya naturaleza estaba en el tiempo, no fuera de él. El resultado inevitable de esa "naturaleza" era la negación de sí misma, la metamorfosis (Pocock, 1985, p. 170).

\section{EL OCASO DEL PENSAMIENTO POLÍTICO CLÁSICO EN LAS TRECE COLONIAS}

Una consecuencia perceptible de estas transformaciones sociales en el pensamiento político de las Trece Colonias aparece en la manera de justificar el gobierno representativo. Hasta ese momento la representación se había visto como una variante de la democracia. Por supuesto, políticos e intelectuales no creían que la América anglófona tuviese una democracia "pura". Un régimen de este tipo implicaba que el pueblo gobernara sin intermediarios, pero los colonos elegían representantes; a lo sumo podían afirmar que el pueblo gobernaba "a través" de ellos. Sin embargo, el intelectual o político promedio 
en las Trece Colonias antes de 1776 creía sinceramente que no había separación entre el poder político y el "soberano" (Bailyn, 1972, p. 169). El nacimiento de la Unión, los debates constitucionales entre 1787 y 1789, cambiaron la manera de percibir la cuestión política en Estados Unidos.

En Filadelfia, sobre la representación, el primer punto de debate fueron los requisitos para ejercer el voto y optar por un puesto en la Cámara de Representantes y el Senado. Vale aclarar que todavía en 1787 había requisitos patrimoniales para votar y ser elegido en la mayoría de los estados (Corcho, 2019, pp. 67-70). Las opiniones giraron en torno a cuál era el monto adecuado y qué tipo de propiedad debía incluirse en la Constitución para ejercer los derechos políticos, si sólo la propiedad de bienes inmuebles o también la de bienes muebles. De esta encrucijada dependía el acceso de los artesanos, comerciantes y, más tarde, los desposeídos de cualquier fortuna a los derechos políticos. Por supuesto que en esa discusión hubo intereses económicos y políticos manifiestos. Pero aquí me centraré en los argumentos que los contrincantes utilizaron -por convicción o conveniencia- en la disputa.

La opinión de los más conservadores, defendida vivamente por Gouverneur Morris y John Dickinson, sostenía que sólo los propietarios rurales debían tener derecho a votar y ser elegidos. Para defender el porqué de las exigencias patrimoniales recurrieron a la idea según la cual la libertad y la propiedad rural están entrelazadas, siguiendo el pensamiento político clásico. Si la Convención hubiese seguido las opiniones de Dickinson y Morris, los propietarios urbanos habrían carecido de derechos políticos. ${ }^{3}$ Los conservadores en la Convención daban por cierto que la libertad iba de la mano de la tierra poseída, pero no decían por qué un propietario urbano nunca llegaría a ser libre. Governeur Morris declaró lo siguiente: "no está lejano el día cuando en este país abundarán los artesanos y fabricantes, que recibirán su pan de sus empleadores. ¿Serán tales hombres los guardianes seguros y fieles de la libertad?" No, pues "el hombre que no da su voto libremente no está representado" (Farrand, 1911, vol. II, pp. 202-203). En cuanto a los comerciantes, "si

${ }^{3}$ El razonamiento completo de Dickinson es el siguiente: "[Dickinson] considered them [a los freeholders] as the best guardians of liberty. And the restriction of the right [to vote] to them as a necessary defense against the dangerous influence of those multitudes without property \& without principle, with which our Country like all others, will in time abound. As to the unpopularity of the innovation it was in his opinion chimerical. The great mass of our Citizens is composed at this time of freeholders, and will be pleased with it". John Dickinson, discurso del 7 de agosto de 1787 (Farrand, 1911, vol. II, p. 202). 
tienen riqueza y valoran el derecho, pueden adquirir" tierras, y así convertirse en auténticos varones republicanos. Si no, pues no merecen el alto título. En apariencia, los artesanos y fabricantes de que habla no son ni siquiera propietarios, pero en realidad lo son: son propietarios de bienes muebles, y ese era el gran problema para los conservadores. ${ }^{4}$

Los demócratas fueron más generosos con los estratos sociales emergentes. Lo primero que destaca es su repulsa a seguir pensando la representación en términos que ya se sometían a crítica en ambas orillas del mundo anglosajón. Había que encontrar un requisito de participación basado en la propiedad más incluyente y, al mismo tiempo, liberar las mentes de los residuos espirituales de la metrópoli, como lo reconoce George Mason en el siguiente fragmento:

Todos sentimos con fuerza los restos de prejuicios antiguos, y vemos las cosas demasiado a través del modelo británico. La propiedad rural es la única concebible en Inglaterra, y por consiguiente se imagina que es la única apropiada. La idea verdadera es que todo hombre que tenga evidencia de vinculación y un interés común permanente con la Sociedad, debería compartir todos sus derechos y privilegios [...]. ¿Ningún otro tipo de propiedad, más que la tierra, evidencia un interés por el bien común en el propietario? ¿Nada, aparte de la propiedad, marca un apego permanente? ¿El mercader, el hombre de dinero, el padre cuyos hijos deben encontrar la fortuna en su país, deben ser vistos como personajes sospechosos e indignos de que se les confíen los derechos de sus conciudadanos? (Farrand, 1911, vol. II, p. 203).

La realidad que aconsejaba la ampliación del censo electoral era la misma entrevista de Dickinson y Morris, sólo que sus contrincantes veían en ello un proceso reconciliable con la doctrina que juntaba libertad y propiedad. A pesar de contarse en el partido contrario, las opiniones generalmente moderadas de Madison lo condujeron en este caso a defender el criterio de los demócratas. El delegado por Virginia reconocía que los propietarios eran los depositarios más seguros de la libertad, pero coincidía con la opinión de

${ }^{4}$ Esta fue la intervención de Dickinson sobre el punto, que coincide con la de Morris: los requisitos patrimoniales eran "a necessary defense against the dangerous influence of those multitudes without property [rural] \& without principle, with which our Country like all others, will in time abound". Dickinson, discurso del 7 de agosto de 1787 (Farrand, 1911, vol. II, p. 202). 
Mason. Por eso recomendaba para definir el derecho de sufragio algún tipo de criterio que no fuera la mera posesión de tierras, y ese criterio debía basarse en las tres clases de propietarios de la nación: los hacendados, los comerciantes y los fabricantes (Farrand, 1911, vol. II, pp. 123-124).

Lo llamativo de la Convención fue la opinión casi unánime a favor de requisitos patrimoniales. No se discutió tanto si la propiedad era o no el sustento de la libertad cuanto qué tipo y cuál monto eran los apropiados. En este sentido, Filadelfia es una reforma, más que una revolución, del dogma clásico sobre la relación entre libertad y propiedad, obligada por la expansión del comercio y la manufactura. Claro que la Constitución, como se sabe, no incluyó limitaciones patrimoniales sobre los derechos políticos (Keyssar, 2000 , p. 24). Pero ese fue un resultado involuntario, porque los delegados nunca lograron ponerse de acuerdo sobre un requisito que contentara los intereses comerciales del Norte y los agrarios del Sur (Manin, 1998, p. 135). Es decir, si hubiesen llegado a un acuerdo, esos requisitos habrían quedado escritos en la Carta Magna. En cualquier caso, la discusión sobre la propiedad y los derechos políticos fue de aquellas donde aparece con mayor claridad la crisis de las viejas ideas al tomar contacto con la modernidad.

Si el debate sobre la propiedad se interesaba, por decirlo en el viejo lenguaje marxista, por la "infraestructura" de la representación, el próximo lo hace por la "superestructura". Por supuesto, es sólo una analogía útil. En estricto sentido, este nuevo debate deja a un lado la cuestión del patrimonio y aborda la relación entre gobernantes y gobernados. En Filadelfia tanto como las polémicas que ocurrieron hasta 1789 para ratificar la Constitución en cada estado, destacó un bando democrático que la historiografía llama "antifederalista". ${ }^{5}$ Los antifederalistas suponían que cada individuo aspiraba por naturaleza a gobernarse sin intermediarios, pero viendo que no podía hacerlo, delegaba en otros la autoridad de gobernar. El punto central era aquí el deseo natural, intrínsecamente humano, de la democracia. Frente a esa realidad más real que el mundo histórico y social, el gobierno era a lo sumo un mal necesario. Iba implícito en la doctrina que un gobierno sometido al poder del pueblo era el premio de consolación para gente que, de haber podido, se hubiese gobernado a sí misma.

En realidad, había una contradicción latente en el modo de pensar de los antifederalistas; su ideal era una democracia "pura", pero debían conten-

\footnotetext{
${ }^{5}$ No todos eran demócratas, pero sí la mayoría.
} 
tarse con la representación. Noah Webster comprendió como ningún otro teórico las incoherencias internas del radicalismo democrático (Wood, 1969, p. 377). Lo que percibió señala la esencia del gobierno representativo: ¿por qué, si los representantes salían de la entraña del pueblo y eran parte del pueblo, estaban sometidos a constantes supervisiones y debían dar cuenta de su quehacer, como si fuesen "otra cosa"? No había idea más absurda, decir que el pueblo debía vigilar a sus representantes, gente tan popular como ellos, tan campesina o burguesa y tan protestante como ellos. "Una Declaración de Derechos contra las intrusiones de Reyes y Barones, o contra cualquier poder independiente del pueblo, es perfectamente inteligible; pero una Declaración de Derechos contra las intrusiones de una Legislatura electiva, es decir, contra nuestra intrusión en nuestros propios asuntos, es una curiosidad como forma de gobierno" (Webster, 1790, p. 45).

Los estadunidenses debían comprender que los representantes eran parte del pueblo, por lo que tenían su mismo interés. Y esta unión de intereses entre los representantes del soberano y el soberano era la única y verdadera defensa de la libertad popular (Webster, 1790, p. 51). Una y otra vez, a lo largo de sus muchos artículos y ensayos, subyace una preocupación: ¿debía existir la separación de poderes entre representantes y representados? Toda la crítica de Webster a las instrucciones dirigidas a los representantes estaba asentada en su convicción, la convicción básica de la ortodoxia política del siglo XVIII en las Trece Colonias, de que los representantes tenían todo el poder, porque ese poder emanaba en su totalidad, era coextensivo y nunca diferente ni separado del poder del pueblo (Wood, 1969, pp. 328-333).

A pesar de que Noah Webster tenía una enorme capacidad lógica y un ánimo polémico y crítico, sus armas las había forjado en el fuego moribundo del derecho natural: creía en la comunión natural entre pueblo y gobierno. Pensadores como Josiah Tucker y James Madison comprendieron que en la unión de representación y derecho natural había un error. Lo interesante en el razonamiento de estos hombres fue que percibieron el fondo veladamente religioso del derecho natural y su incompatibilidad con la noción moderna de la historia y la política. Todo sistema de acción política, toda distribución de autoridad civil entre seres humanos depende de mi capacidad para reconocer que los otros tienen el derecho de actuar por mí y la autoridad de comprometerme a la obediencia o al desacato mediante estas acciones. Pero al decir que todas mis acciones las realizo como exteriorización de mi naturaleza moral, no sólo niego a otros el derecho a gobernarme, sino también la suposición de 
que soy un ser moral, porque ningún ser moral puede autorizar a que gobiernen en su nombre, ya que la delegación del gobierno en otros es una negación antinatural de mi ser. Al unir la capacidad política del hombre con su naturaleza moral, se excluyen a la vez los principios de autoridad y representación. Josiah Tucker, en su notable ensayo sobre la naturaleza del gobierno representativo $-A$ treatise concerning civil government-, dejó claro, ya a mediados del siglo xviII, que la representación se ajustaba mejor a las repúblicas comerciales porque no se basaba en una concepción estática y moralista de la política, sino en la suposición de que la política se fundaba en relaciones sociales (Pocock, 1985, p. 170).

Habiendo perdido la fe en la unión natural ${ }^{6}$ entre gobernantes y gobernados, los antifederalistas recurrieron a un artificio ya esgrimido otras veces en las colonias: la representación descriptiva (Bailyn, 1972, p. 156). Claro que ese es un término acuñado por Hanna Pitkin (1967) en su libro The concept of representation. Los antifederalistas decían que el gobierno debía ser similar en su composición al genio y la contextura del pueblo. A su juicio, la federación iba contra ese anhelo. Por ejemplo, Brutus, seudónimo tras el cual al parecer se escondía el neoyorquino Robert Yates, observó en el New York Journal:

De acuerdo con el devenir común de los asuntos humanos, será elegida la aristocracia natural del país. La riqueza siempre crea influencia y esta, en general, se ve incrementada por las conexiones de las grandes familias: esta clase en la sociedad siempre tendrá una gran cantidad de clientes; además, siempre se favorecerán entre sí [...], por lo tanto, unirán constantemente sus esfuerzos para procurar que sean elegidos hombres de su propio rango [...]. Es probable que pocos comerciantes, salvo los más opulentos y ambiciosos, tengan representación en este órgano: pocos son personajes lo suficientemente llamativos para atraer la atención de los electores de un estado con tan limitada representación (Storing, 1985, p. 125).

Obsérvese la frase utilizada por Brutus: "de acuerdo con el devenir común de los asuntos humanos". El autor estaba convencido de que era una práctica antigua, con una lógica propia, la que colocaba en los cargos de mando a la "aristocracia natural". ¿Qué entendían entonces por "aristocracia

"El término exacto que se usaba entonces era "virtual representation". 
natural"? Melancton Smith explicó en la asamblea de ratificación de Nueva York (1787) lo que se entendía en aquella época por este término:

Me preguntarán qué pretendo decir con aristocracia natural y me dirán que entre nosotros no existe esta distinción de personas por clases. Es verdad que, para nuestra singular felicidad, carecemos de distinciones legales o hereditarias de este tipo, pero, aun así, hay diferencias reales. El Creador de la naturaleza ha dotado a unos con más aptitudes que a otros: nacimiento, educación, talento y riquezas crean diferencias entre los hombres tan visibles y tan influyentes como los títulos, los galones y las medallas. En toda sociedad, los hombres de esa clase dispondrán de mayor grado de respeto. Y si el gobierno se constituye de tal modo que admita sólo a unos pocos en el ejercicio del poder, éste, siguiendo el curso natural de las cosas, estará en sus manos (Storing, 1985, pp. 340-341).

Smith expresaba una consciencia que cualquier estadunidense tenía por cierta a fines del siglo XVIII, poco antes de que comenzara la jornada constitucional: el poder social confería poder político. Comprobarlo había sido descorazonador para el partido democrático, porque el pueblo se entregaba con absoluta naturalidad a la veneración de la riqueza y el prestigio de los patricios. Era el pueblo quien los elegía como representantes y era la experiencia la que enseñó esa realidad, opacada por la retórica idealista (Wood, 1969, p. 491). Los demócratas no tenían cómo negarla. Abrir los ojos a la expansión del conflicto social que había provocado la economía comercial y la revolución, los dejó sin más armas que la apelación retórica y ética al gobierno del pueblo, por el pueblo y para el pueblo.

Los federalistas explotaron esta debilidad. Por supuesto que el gobierno no se parecería al pueblo, y era bueno que ocurriera así, al decir de ellos. En un pasaje famoso de El Federalista número 10, Madison explica que la elección de gobernantes superiores a sus electores permitía:

la delegación del gobierno en [...] un reducido grupo de ciudadanos elegidos por el resto [...]. Siendo su efecto, por un lado, refinar y extender las opiniones del pueblo pasándolas a través de un órgano electo de ciudadanos, cuya sabiduría mejor pueda discernir los verdaderos intereses de la nación y cuyo patriotismo y amor a la justicia tenga menos probabilidades de ser sacrificados por consideraciones temporales o parciales (Hamilton, Madison y Jay, 1990, pp. 46-47). 
En este fragmento no hay ni sombra del deseo de representación descriptiva que informa los discursos y ensayos de la facción democrática. Claro que Madison no se conforma con la selección de los más inteligentes y virtuosos; no hay fe ciega en las elites inteligentes y virtuosas. Hay que mantener a los representantes en la senda de la virtud con un sistema de imperativos, sanciones y recompensas. La precaución más efectiva para mantenerlos virtuosos son las elecciones y reelecciones frecuentes. La constante perspectiva de unas elecciones próximas combinada con el deseo de seguir en el cargo garantizará una conveniente dedicación a los intereses del pueblo. Si los "pocos" sirven al bien común en vez de a sus propios intereses, no se debe a ningún parecido con sus electores, sino ante todo a que las elecciones constantes los comprometen con el pueblo. Los demócratas radicales pensaban que, para que los representantes sirvieran a la ciudadanía, debían ser como esta. Madison responde que los mejores guardianes del interés colectivo son las elecciones recurrentes, no la proximidad social (Manin, 1998, p. 185).

La fortaleza de la posición de Madison y los delegados que pensaban como él residía en que al decir que el pueblo podía elegir a quien quisiera, estaban afirmando una verdad incuestionable. Cuando Madison dirigió su prosa contra los adversarios de la Constitución, lo primero que hizo fue recurrir a su dimensión democrática y afirmar que el pueblo elegiría a sus representantes y que a nadie se le prohibía llegar al gobierno:

¿Quiénes van a ser los electores de los representantes federales? No los ricos más que los pobres; no los instruidos más que los ignorantes; no los altivos herederos de distinguidos apellidos más que los humildes hijos de suertes oscuras y poco propicias. Los electores serán el gran cuerpo ciudadano de los Estados Unidos [...]. ¿Quiénes serán objeto de elección popular? Todos los ciudadanos cuyos méritos les recomienden ante la estima y confianza de este país. No está permitida ninguna cualificación por riqueza, por nacimiento, credo o profesión que ponga trabas al juicio o engañe la inclinación del pueblo (Hamilton, Madison y Jay, 1990, p. 295).

Y en verdad, Madison no decía ninguna mentira. Cuando defendía el derecho del pueblo a elegir y ser elegido estaba diciendo una verdad, pero también sabía que los electores seleccionan como sus gobernantes a ciudadanos de mérito. El punto esencial es que las dos proposiciones son ciertas. Ambas se completan y una no puede considerarse negación de la otra. El 
bando aristocrático lo intuyó y utilizó ese hecho a su favor. Por esta razón, sabían que el deseo de similitud sociológica entre gobernantes y gobernados a que aspiraban sus contrincantes era una utopía (Manin, 1998, p. 185).

Lo que aceptaron los federalistas es eso que Carl Schmitt llamó "principio de representación"; es decir, que un régimen político puede tener dos dimensiones complementarias -incluso antitéticas-. El gobierno representativo tiene una base democrática que se limita, al menos, a la participación de los gobernados en la elección de los gobernantes, y tiene una cúspide aristocrática, ya que los gobernantes serán elegidos porque los gobernados los perciben como "superiores" a ellos mismos. No tienen que ser "esencialmente superiores", sino sólo vistos como tal por el pueblo. Si la estructura de la representación garantiza autonomía relativa de una dimensión frente a la otra, quiere decir que los gobernantes tomarán decisiones a veces por su cuenta, sin consultar a los gobernados. Por supuesto que esto último es una consecuencia no democrática del gobierno representativo, algo que percibieron claramente los antifederalistas. Por eso los federalistas abogaban por el famoso sistema de checks and balances. La división de poderes, las elecciones periódicas, hacer que la ambición se enfrente a la ambición, tienen como objetivo controlar a los gobernantes sin recurrir a la supervisión popular.

Lo que hicieron los federalistas fue romper la unión entre la dimensión ética y la práctica del gobierno representativo. Cuando un ideólogo estadunidense del siglo XVIII, digamos el propio Noah Webster, se refería al gobierno representativo, hablaba de la realidad empírica y la necesidad ética de la comunión entre gobernantes y gobernados. Los federalistas se contentaron con que los gobernantes se sometieran a razón por medio de artificios políticos de cuya imperfección estaban seguros, como el propio Madison reconoció. Puedo resumir el giro de la siguiente manera: hacia fines del siglo XVIII, la concepción del gobierno representativo había abandonado la idea de una virtud en el ser de las cosas para colocarla en el deber ser, que es el ámbito de lo deseable, mas no de lo seguro. Este deseo de ver a la virtud haciéndose dueña de la república, aunque ya no hubiera certeza de su victoria, es la última supervivencia del pensamiento político clásico en la doctrina del gobierno representativo en las Trece Colonias. La virtud quedó así suspendida sobre la realidad, sobre "la facilidad con que pocos gobiernan a muchos; la sumisión implícita que lleva a los pueblos a renunciar a sus propios sentimientos y pasiones en favor de aquellos de sus gobernantes", como dijera Hume (1963, p. 29). La diosa Fortuna y su corte de comerciantes, hacendados y artesanos 
fue la responsable de proscribir la ilusión de la concordia entre "pocos" y "muchos" al reino del quizá. Por la hendidura ahora podía entrar la voz de quienes aconsejaban la égida de los pocos, siempre y cuando gobernasen con el consentimiento de los muchos.

$\mathrm{Al}$ aceptar que no hay nada malo a priori en ser gobernado por otro, desaparece el carácter espectral y subordinado del gobierno. Nace entonces una relación entre dos sujetos políticos, igualmente autónomos, en la cual ambos se vigilan y afectan. Esta nueva concepción de la política tiene como trasfondo un tipo antropológico diferente al del derecho natural. Se ve al hombre como ser social, no como depositario de esencias inmutables. La nueva economía comercial, al generar mayor libertad y contacto constante entre cosas y hombres, aceleró los cambios de conciencia que venían ocurriendo desde el siglo XVII.

\section{LISTA DE REFERENCIAS}

Appleby, J. (1984). Capitalism and the new social order: The republican vision of the 1790 s. Nueva York: New York University Press.

Appleby, J. (1992). Liberalism and republicanism in the historical imagination. Cambridge: Harvard University Press.

Bailyn, B. (1972). Los orígenes ideológicos de la revolución americana (trad. A. Vanasco). Buenos Aires: Paidós.

Casassas, D. (2010). La ciudad en llamas: la vigencia del republicanismo comercial de Adam Smith. Barcelona: Montesinos.

Corcho, D. (2019). Representación, prácticas sociopolíticas e ideología en la época de la Revolución Americana. (Tesis de maestría). México, El Colegio de México.

Daniels, B. C. (1989). Economic development in colonial and revolutionary Connecticut: An overview. William and Mary Quarterly, 37(3), 429-450. DoI: https://doi. org/10.2307/1923811

Downer, S. (2002). A discourse at the dedication of the tree of liberty. En B. Frohnen (ed.), The american republic, primary sources [1768]. Indianapolis: Liberty Foundation.

Farrand, M. (ed.) (1911). The records of the Federal Convention of 1787 (3 vols.). New Haven: Yale University Press.

Fogel, R. W. y Engerman, S. L. (1974). Time on the cross: The cconomics of American negro slavery. Nueva York: UP of America. 
Genovese, E. y Fox-Genovese, E. (1983). The fruits of merchant capital. Nueva York: Oxford University Press.

Greenberg, M. (1977). William Byrd II and the world of the market. Southern Studies, 16(4), 429-56.

Hamilton, A. (1907). Itinerarium [1744]. W. K. Bixby (ed.). Washington: Library of Congress.

Hamilton, A., Madison, J. y Jay, J. (1990). The federalist. A collection of essays written in favor of the new constitution as agreed upon by the Federal Convention, september, 17, 1787 [1787]. G. W. Carey y J. McClellan (eds.). Dubuque: Kendall/Hunt.

Hartz, L. (1955). The liberal tradition in America: An interpretation of American political thought since the revolution. Nueva York: Harcourt.

Hume, D. (1963). Essays moral, political and literary [1777]. Oxford.

Huntington, S. (1990). El orden político en las sociedades en cambio (trad. M. P. Moreno). Buenos Aires: Paidós.

Kalyvas, A. y Katznelson, I. (2008). Liberal beginnings. Cambridge: Cambridge University Press.

Keyssar, A. (2000). The right to vote. The contested history of democracy in the United States. Nueva York: Basic Books.

Lemon, J. T. (1984). Spatial order: Households in local communities and regions. En J. P. Green y J. R. Pole (eds.), Colonial british America. Baltimore: John Hopkins University Press.

Maier, P. (2010). Ratification. The people debate the Constitution, 1787-1788. Nueva York: Simon \& Schuster.

Manin, B. (1998). Los principios del gobierno representativo (ed. y trad. F. Vallespín,). Madrid: Alianza.

Moore, B. (1976). Los orígenes sociales de la dictadura y la democracia. El señor y el campesino en la formación del mundo moderno (trads. J. Costa y G. Woith). Barcelona: Península.

Nash, G. B. (1984). Social development. En J. P. Greene y J. R. Pole (eds.), Colonial british America. Baltimore: John Hopkins University Press.

Perkins, E. (1980). The economy of colonial America. Nueva York: Columbia University Press.

Pettit, P. (1999). Republicanismo: una teoría sobre la libertad y el gobierno. Buenos Aires: Paidós.

Pitkin, H. (1967). The concept of representation. California: University of California Press. 
Pocock, J. (1985). Virtue, Commerce and history: Essays on political thought and history, chiefly in the eighteenth century. Cambridge: Cambridge University Press.

Pocock, J. (2002a). El momento maquiavélico. El pensamiento político florentino y la tradición republicana atlántica. Madrid: Tecnos.

Pocock, J. (2002b). Historia e Ilustración. Doce estudios (eds. y trads. A. Feros y J. A. Pardos). Madrid: Marcial Pons.

Sheridan, R. B. (1984). The domestic economy. En J. P. Greene y J. R. Pole (eds.), Colonial British America. Baltimore: John Hopkins University Press.

Storing, H. J. (comp.) (1985). The antifederalist. Chicago: University of Chicago Press.

Webster, N., (1790). A collection of essays and fugitive writings on moral, historical, political and literary subjects. Boston.

Wood, G. (1969). The creation of the American republic, 1776-1787. Chapel Hill: University of North Carolina Press. 